Article

\title{
Synthesis, characterization and catalytic reactivity of pentacoordinate iron dicarbonyl as a model of the [Fe]-hydrogenase active site
}

\author{
Tianyong Zhang a,b, Liao Sheng a, Qiusheng Yang c, Shuang Jiang a, Yanhong Wang a, Chaohui Jin a, \\ Bin Li a,* \\ a Tianjin Key Laboratory of Applied Catalysis Science and Technology, School of Chemical Engineering and Technology, Tianjin University, Tianjin 300072, \\ China \\ ${ }^{\mathrm{b}}$ Collaborative Innovation Center of Chemical Science and Engineering (Tianjin), Tianjin 300072, China \\ 'School of Chemical Engineering and Technology, Hebei University of Technology, Tianjin 300130, China
}

\section{A R T I C L E I N F O}

Article history:

Received 16 April 2015

Accepted 23 May 2015

Published 20 November 2015

Keywords:

Mono iron hydrogenase

Model complex

Catalytic transfer hydrogenation

Functional analogue

Benzoquinone

\begin{abstract}
A B S T R A C T
Two mono iron complexes $\mathrm{Fe}(\mathrm{CO})_{2} \mathrm{PR}_{3}(\mathrm{NN})(\mathrm{R}=\mathrm{Cy}(3), \mathrm{Ph}(4), \mathrm{NN}=o$-phenylenediamine dianion ligand, $\mathrm{N}_{2} \mathrm{H}_{2} \mathrm{Ph}^{2-}$ ) derived from the ligand substitution of $\mathrm{Fe}(\mathrm{CO})_{3} \mathrm{I}_{2} \mathrm{PR}_{3}$ by the NN ligand were isolated and structurally characterized by single crystal X-ray diffraction. They have a similar first coordination sphere and oxidation state of the iron center as the [Fe]-hydrogenase active site, and can be a model of it. IR demonstrated that the effect of the NN ligand on the coordinated CO stretching frequencies was due to its excellent electron donating ability. The reversible protonation/deprotonation of the NN ligand was identified by infrared spectroscopy and density functional theory computation. The NN ligand is an effective proton acceptor as the internal base of the cysteine thiolate ligand in [Fe]-hydrogenase. The electrochemical properties of complexes 3, 4 were investigated by cyclic voltammograms. Complex $\mathbf{3}$ catalyzed the transfer hydrogenation of benzoquinone to hydroquinone effectively under mild conditions.
\end{abstract}

(C) 2015, Dalian Institute of Chemical Physics, Chinese Academy of Sciences. Published by Elsevier B.V. All rights reserved.

\section{Introduction}

[Fe]-Hydrogenase (Hmd) participates in the methanogenic process of the reduction of $\mathrm{CO}_{2}$ to methane. In the presence of the substrate $\mathrm{N}^{5}, \mathrm{~N}^{10}$-methenyl-tetrahydro-methnanopterin (methenyl- ${ }_{4} \mathrm{MPT}^{+}$, or $\mathrm{MPT}^{+}$), the enzyme catalyzes the heterolytic cleavage of $\mathrm{H}_{2}$ (Scheme 1) [1,2].

Methenyl- $\mathrm{H}_{4} \mathrm{MPT}^{+}$accepts $\mathrm{H}^{+}$ions and forms $\mathrm{N}^{5}, \mathrm{~N}^{10}$-methylene-tetrahydromethanopterin (methylene- $\mathrm{H}_{4} \mathrm{MPT}$, or HMPT) [2]. The other proton from $\mathrm{H}_{2}$ exchanges rapidly with the protons of the bulk water, while the immediate proton acceptor is unknown. In the active site of Hmd [3-8], the Fe ion has the ligands of one cysteine sulfur atom, two cis-CO ligands, and one bi-dentate donor atom of guanylylpyridinol cofactor through its nitrogen and acyl-carbon atoms (Fig. 1.) [6,9-11]. The coordination site trans to the acyl ligand was proposed to be the $\mathrm{H}_{2}$-binding site. It is unclear whether this site is vacant or occupied by a solvent molecule, most likely a water molecule, in the resting state.

A mechanism based on the resting state model of wild-type Hmd [6,9] was proposed from DFT (density functional theory) calculations. The $\mathrm{MPT}^{+}$substrate triggers the $\mathrm{H}^{+}$release to re-

\footnotetext{
* Corresponding author. Tel/Fax: +86-22-27406610; E-mail: libin@tju.edu.cn This work was supported by the National Natural Science Foundation of China (21103121, 21276187), Tianjin Municipal Natural Science Foundation (13JCQNJC05800) and the Specialized Research Fund for the Doctoral Program of Higher Education (20121317110009). 


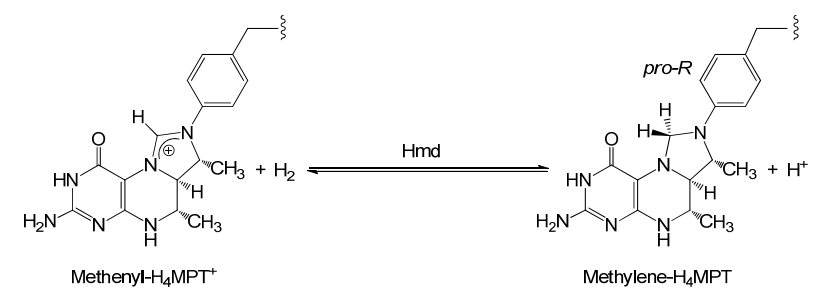

Scheme 1. Reversible hydrogen transfer reduction catalyzed by Hmd.

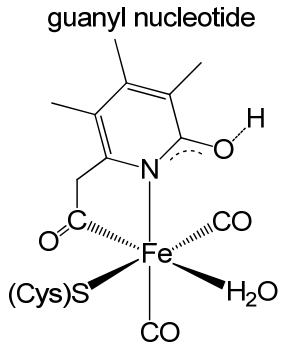

Fig. 1. The proposed active site of Hmd.

generate the resting state with the $\mathrm{Fe}-\mathrm{H}^{\delta+} \cdot \cdots \mathrm{H}^{\delta-}-\mathrm{O}$ dihydrogen bond after the proton transfers from the Cys176-sulfur or 2-pydinol's oxygen [12]. The cysteine thiolate ligand in the open site which initially helps bind $\mathrm{H}_{2}$ and then works as the internal base in the theory is the possible proton acceptor in the reaction. Some models have been developed to prove that the cysteine thiolate ligand has the reversible protonation property, but it is still a challenge to activate the dihydrogen [4-8]. This motivated us to develop more viable alternative ligands to focus on the function of hydrogenation.

Catalytic hydrogenation via transition metal complexes has demonstrated in 1995 that the interaction of intermolecular and intramolecular $\mathrm{M}-\mathrm{H} \cdot \cdots \mathrm{H}-\mathrm{N}$ bonds were strong. Intermolecular H-bonds have been used to design the structure and catalytic activity of a transition metal complex in asymmetric hydrogenation reactions [13]. In the use of [FeFe]-hydrogenase [3], it is generally accepted that the coordination and subsequent heterolytic cleavage of dihydrogen occured at an iron center [14]. The reaction is likely facilitated by an amine of the proposed azadithiolate cofactor. In addition, a Noyori-type hydrogenation system based on the diamine- $\mathrm{RuCl}_{2}$ complex functions by "metal-ligand bifunctional catalysis" for the hydride transfer to an outer sphere molecule [15], which is similar to the trigger mechanism of Hmd. Noyori [15] found that an unsubstituted diamine was critical and the catalyst would be ineffective when diamines without $\mathrm{NH}$ groups were used. The so-called "NH-effect" has been widely investigated and was proposed to stabilize an incoming ketone substrate [16]. A similar structure and catalytic mechanism have been found in a transition metal complex like tris(o-phenylenediamine) iron(II). Transition metal ions coordinated by a nitrogen ligand have a unique property in hydrogen transformation. Aromatic amines and hydroxides, such as phenylenediamine or hydroquinone derivatives, are widely known to possess $2 \mathrm{H}^{+} / 2 \mathrm{e}^{-}$ pulling capability, which resembles the function of the internal base in the [Fe]-hydrogenase enzyme [17]. This inspired us to utilize an organic skeleton coordinated with a nitrogen or binitrogen ligand to mimic the hydrogenation to obtain a func- tional model of Hmd. In this paper, two new functional mono-iron hydrogenase active site models coordinated by a NN ligand were synthesised and characterized. The introduced NN ligand served as an internal base, which can undergo reversible protonation/deprotonation with the acid $\left(\mathrm{HBF}_{4}\right.$ or $\mathrm{AcOH} /$ ethanediamine). The developed models also catalyzed the hydrogenation of quinone under mild conditions.

\section{Experimental}

\subsection{General procedures}

All synthetic operations and measurements were conducted under a $\mathrm{N}_{2}$ atmosphere using Schlenk line techniques because the precursors of these iron-series complexes are sensitive to light and air. Hence, the solvents, including $n$-hexane and tetrahydrofuran (THF), were distilled with $\mathrm{Na}$ metal to remove trace water, and were preserved with $4 \mathrm{~A}$ sieves before use. Complexes $\mathrm{FeI}_{2}(\mathrm{CO})_{4}, \mathrm{FeI}_{2}(\mathrm{CO})_{3} \mathrm{PCy}$ and $\mathrm{FeI}_{2}(\mathrm{CO})_{3} \mathrm{PPh}_{3}$ were prepared according to literature procedures. The following materials were reagent grade and used as purchased from Sigma-Aldrich: potassium tert-butoxide, $o$-phenylenediamine and $n-\mathrm{Bu}_{4} \mathrm{NPF}_{6}$. The $\mathrm{Fe}(\mathrm{CO})_{5}$ was obtained as a gift from Jiangsu Tianyi Ultra-fine Metal Powder Co., Ltd (China).

The NMR spectra were measured on a Bruker AVANCE III $400 \mathrm{MHz}$ NMR spectrometer. ${ }^{1} \mathrm{H}$ NMR shifts were referenced to residual solvent resonances according to literature values. The solution IR spectra was recorded on a Shimadzu FTIR-8400 spectrometer using $0.1 \mathrm{~mm} \mathrm{KBr}$ sealed cells. Quinone and hydroquinone samples were analyzed by reversed phase high performance liquid chromatography (C18, $\phi 150 \times 4.6 \mathrm{~mm}$ ) using an external standard method on an Agilent 1100 spectrometer. The mobile phase was $\mathrm{CH}_{3} \mathrm{CN} / \mathrm{H}_{2} \mathrm{O}(30 / 70, V / V)$ and the flow rate was $1.0 \mathrm{~mL} / \mathrm{min}$. The measurement was performed at the wavelength of $298 \mathrm{~nm}$.

\subsection{Synthesis of complex $\mathbf{3}$ and $\mathbf{4}$}

Scheme 2 shows the synthetic route for the preparation of $\mathrm{Fe}(\mathrm{CO})_{2} \mathrm{PR}_{3}(\mathrm{NN})$. The precursors were obtained via the $\mathrm{CO}$ ligand substitution reaction of $\mathrm{FeI}_{2}(\mathrm{CO})_{4}$ and $\mathrm{PR}_{3}\left(1: 1, \mathrm{R}=\mathrm{PCy}_{3}\right.$, $\mathrm{PPh}_{3}$ ) following the procedure reported by Li et al [18]. First, a solution of $\mathrm{FeI}_{2}(\mathrm{CO})_{3} \mathrm{PCy}_{3}(500 \mathrm{mg}, 0.742 \mathrm{mmol}$ ) dissolved in THF (100 mL) was prepared. Then, $o$-phenylenediamine (240 $\mathrm{mg}, 2.22 \mathrm{mmol}$ ) and $t$-BuOK (500 $\mathrm{mg}, 4.44 \mathrm{mmol}$ ) were mixed under stirring for $10 \mathrm{~min}$ in a flask, to which THF (50 mL) was added later. A bluish violet well-proportioned and stable solution was generated. The solution was transformed into a third Schlenk flask at the same ratio and intervals during $1 \mathrm{~h}$ and then keep stirred for $1.5 \mathrm{~h}$. Afterwards $0.1 \mathrm{~mL}$ water was added into the system to react with the excess $o$-phenylenediamine dianion and then the solvent was removed in vacuo. After extraction with $n$-hexane and filtration through celite, the filtrate was dried in vacuo to yield the crude product including the target 3 (250 mg 30\%) and byproduct trans-[Fe(CO) $\left.3\left(\mathrm{PCy}_{3}\right)_{2}\right]$. The crude product can be used for single crystal growth by slow evaporation of the $n$-hexane solution of 3 . The purified 
crystals were used for the characterization including NMR and elemental analysis. Complex 4 used a similar preparation process. However, it was more difficult to get the pure product of 4 for further characterization due to its poor stability.

Complex 3: ${ }^{1} \mathrm{H}$ NMR $\left(400 \mathrm{MHz}, \mathrm{CD}_{2} \mathrm{Cl}_{2}\right): \delta=9.04(\mathrm{~s}, 1 \mathrm{H}$, $\left.\mathrm{PhN}_{2} \mathrm{H}_{2}\right), 7.69\left(\mathrm{~s}, 1 \mathrm{H}, \mathrm{PhN}_{2} \mathrm{H}_{2}\right), 7.20\left(\mathrm{~s}, 2 \mathrm{H}, \mathrm{PhN}_{2} \mathrm{H}_{2}\right), 6.87(\mathrm{br}, 2 \mathrm{H}$, $\left.\mathrm{PhN}_{2} \mathrm{H}_{2}\right), 1.84\left(\mathrm{br}, 12 \mathrm{H}, \mathrm{PCy}_{3}\right), 1.74\left(\mathrm{~s}, 6 \mathrm{H}, \mathrm{PCy}_{3}\right), 1.43(\mathrm{~s}, 3 \mathrm{H}$, $\left.\mathrm{PCy}_{3}\right), 1.25\left(\mathrm{br}, 12 \mathrm{H}, \mathrm{PCy}_{3}\right) .{ }^{13} \mathrm{C} \operatorname{NMR}\left(100 \mathrm{MHz}, \mathrm{CDCl}_{3}\right): \delta=$ 221.11, 220.97(s, 2C, CO), 29.28(s, 1H, PhCR $)$. Elemental analysis (\%) calculated for $\mathrm{C}_{26} \mathrm{H}_{39} \mathrm{FeN}_{2} \mathrm{O}_{2} \mathrm{P}$ : C 62.60, $\mathrm{H}$ 7.88, N 5.63; found C 62.45, H 7.95, N 5.52.

\subsection{Synthesis of complex $\mathbf{3}-\mathbf{H}^{+}$}

Complex $3-\mathbf{H}^{+}$was prepared by the protonation of complex 3 (100 mg, $0.2 \mathrm{mmol}$ ) with $\mathrm{HBF}_{4}(0.2 \mathrm{mmol})$ in acetone under stirring condition. After $10 \mathrm{~min}$, a light yellow precipitate was formed. The precipitate was collected by filtration, and dried under vacuum to afford the crude product of $3-\mathbf{H}^{+}(80 \mathrm{mg}, 0.16$ mmol). Further characterization failed due to the decomposition of the crude product of $\mathbf{3}-\mathbf{H}^{+}$during the purification.

\subsection{Single crystal $X$-ray diffraction}

Single crystal X-ray diffraction data were collected with a Rigaku MM-007 diffractometer equipped with a Saturn 724CCD. Data were collected at (173 K) using a confocal monochromator with Mo- $K_{\alpha}$ radiation $(\lambda=0.71073 \AA)$. Data collection, reduction and absorption correction were performed with the CRYSTALCLEAR program. The structure was solved by direct methods using the SHELXS-97 program and refined by full matrix least squares techniques (SHELXL-97) on $F^{2}$. Hydrogen atoms were located by geometry calculations. CCDC 1050778 and 1050779 for complexes $\mathbf{3}$ and $\mathbf{4}$ contain the supplementary crystallographic data for this paper which can be obtained from the Cambridge Crystallographic Data Centre via www.ccdc.cam.ac.uk/data_request/cif.

\subsection{Cyclic voltammetry}

Cyclic voltammograms were obtained in a three-electrode cell under $\mathrm{N}_{2}$ using a $\mathrm{CHI} 660 \mathrm{~B}$ electrochemical workstation. The working electrode was a glassy carbon disc (diameter 3 $\mathrm{mm}$ ) polished with $3 \mu \mathrm{m}$ and $1 \mu \mathrm{m}$ diamond paste and sonicated in ion-free water for $20 \mathrm{~min}$ prior to use. The reference electrode was a non-aqueous $\mathrm{Ag} / \mathrm{Ag}^{+}\left(0.01 \mathrm{~mol} / \mathrm{L}\right.$ of $\mathrm{AgNO}_{3}$ in $\mathrm{CH}_{3} \mathrm{CN}$ ) electrode and the counter electrode was platinum wire. A solution of $n-\mathrm{Bu}_{4} \mathrm{NPF}_{6}(0.1 \mathrm{~mol} / \mathrm{L})$ in $\mathrm{CH}_{3} \mathrm{CN}$ was used as the supporting electrolyte, which was degassed by bubbling dry $\mathrm{N}_{2}$ for 10 min before measurement. Ferrocene was used as an external standard under the same measuring conditions and all the potentials were referenced to the $\mathrm{Cp}_{2} \mathrm{Fe}^{+/ 0}$ couple at $0 \mathrm{~V}$.

\subsection{Catalytic hydrogenation}

In a typical experiment, $50 \mathrm{mg}(0.46 \mathrm{mmol})$ quinone and 3 $\mathrm{mg}(0.0056 \mathrm{mmol})$ complex 3 were dissolved in $12.5 \mathrm{~mL}$ of ethanol under stirring in a atmosphere of $\mathrm{N}_{2}(0.1 \mathrm{MPa})$. Samples were taken at $30 \mathrm{~min}$ intervals for HPLC analysis.

\section{Results and discussion}

\subsection{Synthesis of the model complexes}

With the aim to develop a dinitrogen bidentate mono iron model complex of Hmd, the NN ligand, which was obtained from the deprotonation of $o$-phenylenediamine by $t$-BuOK (potassium tert-butoxide), was used to substitute the iodine anion of complex 1 (Scheme 2) [18]. The preparation of the NN ligand was conducted in methanol in early attempts as $t$-BuOK is insoluble in most organic solvents. Combining $\mathbf{1}$ with $o$-phenylenediamine in methanol or a methanol/THF mixed solvent was unsuccessful due to the instability of complex $\mathbf{1}$ in the polar protic solvent. Further experiments revealed that the NN ligand can be obtained by mixing $o$-phenylenediamine and $t$-BuOK powder without a solvent under vacuum. Hence, we improved the experiment methods by dissolving $\mathbf{1}$ and the NN ligand separately in THF, then gradually mixing them, which worked well on the synthetic scale of complex $1 \mathrm{of} \mathrm{ca.} 500 \mathrm{mg}$. FT-IR monitoring showed that $3\left(1965 \mathrm{~cm}^{-1}, 1909 \mathrm{~cm}^{-1}\right)$ and byproduct $\mathrm{Fe}(\mathrm{CO})_{3}\left(\mathrm{PCy}_{3}\right)_{2}$ [19] $\left(1854 \mathrm{~cm}^{-1}\right)$ were generated in the reaction system with the yields of $25 \%(3)$ and $62 \%(5)$, respectively.

Complex $\mathbf{3}$ is soluble in most organic solvents, i.e., $n$-hexane, $\mathrm{CH}_{2} \mathrm{Cl}_{2}$, methanol, acetone etc., slightly dissolved in $\mathrm{CH}_{3} \mathrm{CN}$ and is poorly soluble in water. As a non-polar molecule, the byproduct is insoluble in polar solvent such as methanol, acetone, and $\mathrm{CH}_{3} \mathrm{CN}$. Therefore, a purple-black powder of complex $\mathbf{3}$ can be separated completely from byproduct $\mathbf{5}$ via dissolution in a polar solvent, and then removing the insoluble complex $\mathbf{3}$. It was more difficult to get the pure product of $\mathbf{4}$ than complex $\mathbf{3}$ by a similar way due to the poor stability of complex 4 in the synthesis and purification process [20].

Solid complexes $\mathbf{3}$ and $\mathbf{4}$ are soluble in solvents like $n$-hexane, $\mathrm{CH}_{2} \mathrm{Cl}_{2}$, and $\mathrm{CH}_{3} \mathrm{CN}$. Complex 3 is relatively stable in these solutions even in air, light or at $70{ }^{\circ} \mathrm{C}$. However, complex 4 was not as stable as complex 3 . According to IR monitored results, complex 4 can be handled in the nonpolar solvent of hexane solution for a few hours, but it would partly decompose within a week at $4{ }^{\circ} \mathrm{C}$. Complex 4 decomposed faster in the polar solvents of $\mathrm{CH}_{2} \mathrm{Cl}_{2}, \mathrm{CH}_{3} \mathrm{CN}$ than in the nonpolar solvent of hexane, due to the easy dissociation of the labile CO ligands. However, in the solid state, both complexes $\mathbf{3}$ and $\mathbf{4}$ were stable and can be kept in the refrigerator for 3 months or even longer at $4{ }^{\circ} \mathrm{C}$.

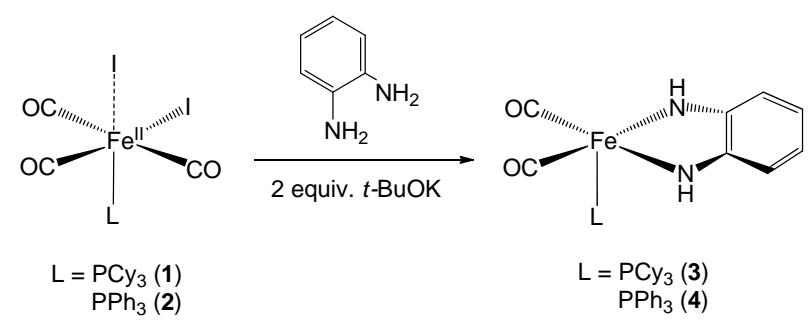

Scheme 2. Synthetic route of complexes 3 and 4. 


\subsection{FT-IR spectroscopy}

The IR spectrum of $\mathbf{3}$ showed two intense $v(\mathrm{CO})$ absorption at 1974 and $1919 \mathrm{~cm}^{-1}$ in hexane solution, which were lower than those of $4\left(1985 \mathrm{~cm}^{-1}, 1929 \mathrm{~cm}^{-1}\right)$ due to the different phosphine ligands introduced. Fig. 2 displays the $v(\mathrm{CO})$ IR spectra for the two bands which had nearly the same intensity, indicating that cis-dicarbonyls were at $90^{\circ}$ angles [4]. The $v(\mathrm{CO})$ band positions of 3 was shifted to a lower frequency by $10 \mathrm{~cm}^{-1}$ as the electron-donating ability of $\mathrm{PCy}_{3}$ is better than $\mathrm{PPh}_{3}$. Actually, complex $\mathbf{3}$ was more stable than complex $\mathbf{4}$ which was evidenced indirectly by the characteristics of the IR spectra. Since $\mathrm{PCy}_{3}$ is more bulky than $\mathrm{PPh}_{3}$, the effect of the electron-donating property on complex stability should overcome the steric effects here. Compared with the previous derivatives (Table 1), the NN ligand serves as a strong electron donor which keeps the complex stable and makes the catalytic hydrogenation possible.

\subsection{X-ray crystallography}

The crude product(100 mg) was dissolved in $n$-hexane first. The solution was stored in a sealed beaker after filtration. Finally rectangle crystals suitable for X-ray diffraction analysis were obtained through gradual solvent volatilization.

The pentacoordinate complex 3 (Scheme 2) was characterized by X-ray crystallography (Fig. 3). The structure of $\mathbf{3}$ is similar to that of $\mathrm{Fe}(\mathrm{CO})_{2} \mathrm{PCy}_{3}(\mathrm{NS})$ [19]. The C1-Fe1-N1 angle is $171.55^{\circ}$ and the $\mathrm{C} 2-\mathrm{Fe} 1-\mathrm{N} 2$ angle is $134.13^{\circ}$. Thus, the coordination geometry of $\mathbf{3}$ can be best described as a distorted trigonal pyramid. It is closer to a distorted square pyramid for complex 4 with the C1-Fe1-N2 angle of $163.14^{\circ}$ and C2-Fe1-N1

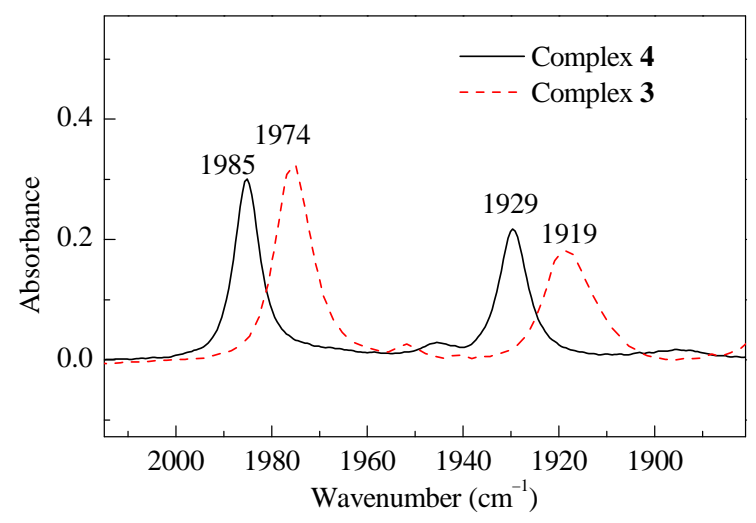

Fig. 2. IR spectra ( $v(\mathrm{CO})$ region) of complexes $\mathbf{3}$ and $\mathbf{4}$ in hexane.

Table 1

Selected IR spectroscopy data.

\begin{tabular}{lcc}
\hline Complex & Solvent & $v(\mathrm{CO}) / \mathrm{cm}^{-1}$ \\
\hline $\mathrm{Fe}(\mathrm{CO})_{2} \mathrm{PCy}_{3}(\mathrm{NN})$ & Hexane & $1974(\mathrm{~s}), 1919(\mathrm{~s})$ \\
$\mathrm{Fe}(\mathrm{CO})_{2} \mathrm{PPh}_{3}$ (NN) & Hexane & $1985(\mathrm{~s}), 1929(\mathrm{~s})$ \\
$\mathrm{Fe}(\mathrm{CO})_{2} \mathrm{PCy}_{3}$ (NS) [Ref. 7] & $\mathrm{CH}_{2} \mathrm{Cl}_{2}$ & $1985(\mathrm{~s}), 1927(\mathrm{~s})$ \\
$\mathrm{Fe}(\mathrm{CO})_{2} \mathrm{PPh}_{3}$ (NS) [ Ref. 7] & $\mathrm{CH}_{2} \mathrm{Cl}_{2}$ & $2002(\mathrm{~s}), 1942(\mathrm{~s})$ \\
$\mathrm{Fe}(\mathrm{CO})_{2} \mathrm{P}(\mathrm{OEt})_{3}$ (NS) [ Ref. 7] & $\mathrm{CH}_{2} \mathrm{Cl}_{2}$ & $2012(\mathrm{~s}), 1956(\mathrm{~s})$ \\
{$\left[\mathrm{Fe}(\mathrm{CO})_{2}\right.$ (CN)(NS) [ Ref. 10] } & $\mathrm{CH}_{2} \mathrm{Cl}_{2}$ & $2000(\mathrm{~s}), 1936(\mathrm{~s})$ \\
Hmd [ Ref. 11] & $\mathrm{THF}$ & $2011(\mathrm{~s}), 1944(\mathrm{~s})$ \\
\hline
\end{tabular}

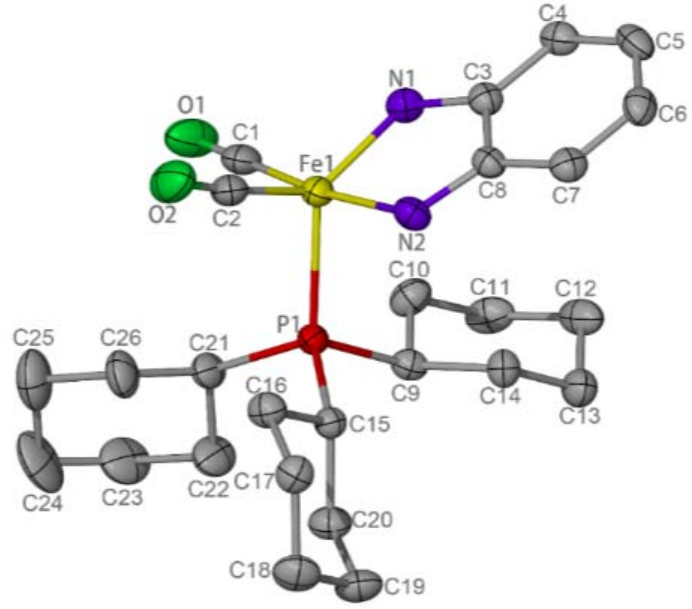

Fig. 3. Solid state structure of 3. The thermal ellipsoids are displayed at $50 \%$ probability. Hydrogen atoms omitted. Selected bond lengths $[\AA ̊]$ and angles $\left({ }^{\circ}\right)$ for 3: Fe1-C1 1.765(4), Fe1-C2 1.750(4), Fe1-N1 1.882(3), Fe1-N2 1.909(3), Fe1-P1 2.2508(12), N1-C3 1.363(4), N2-C8 1.346(4), C3-C8 1.422(5), C3-C4 1.414(4), C7-C8 1.413(4), C4-C5 1.361(5), C5-C6 1.411(5), C6-C7 1.367(5); C2-Fe1-C1 92.43(18), N1-Fe1-N2 80.20(12), C1-Fe1-N2 171.55(14), C2-Fe1-N1 134.13(16), C1-Fe1-N1 91.38(15), C2-Fe1-N2 93.93(15), N1-Fe1-P1 125.91(10), N2-Fe1-P1 91.67(10), C2-Fe1-P1 99.54(12), C1-Fe1-P1 92.76(13).

angle $146.98^{\circ}$.

The NN ligand of both $\mathbf{3}$ and $\mathbf{4}$ coordinates with the iron center by the two amino nitrogen atoms. The two $\mathrm{CO}$ and the phosphine ligand are all mutually cis, while the nitrogen ligand is cis to the nearby CO ligand. The position trans to the phosphine ligand is unoccupied. Both are consistent with the existence of two cis-CO ligands (Fig. 4)[21].

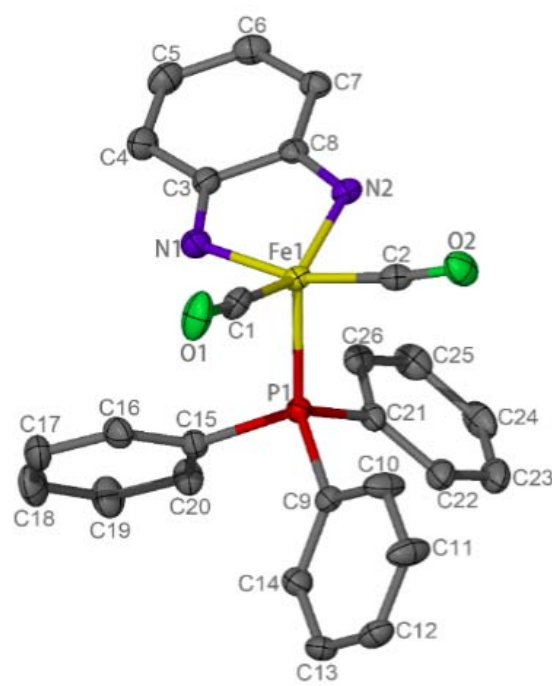

Fig. 4. Solid state structure of complex 4. The thermal ellipsoids are displayed at $50 \%$ probability. Hydrogen atoms omitted. Selected bond lengths $[\AA ̊]$ and angles $\left({ }^{\circ}\right)$ for 4: Fe1-C1 1.766(3), Fe1-C2 1.768(3), Fe1-N2 1.884(2), Fe1-N1 1.900(2), Fe1-P1 2.2258(8), N1-C3 1.362(3), N2-C8 1.361(3), C3-C8 1.420(4), C3-C4 1.411(4), C7-C8 1.409(4), C4-C5 1.368(4), C5-C6 1.407(4), C6-C7 1.375(4), C1-Fe1-C2 92.61(12), N2-Fe1-N1 80.45(10), C1-Fe1-N2 146.88(11), C2-Fe1-N1 162.90(11), N1-Fe1-P1 94.96(8), N2-Fe1-P1 116.88(7), C1-Fe1-P1 95.90(10), C2-Fe1-P1 100.62(9). 

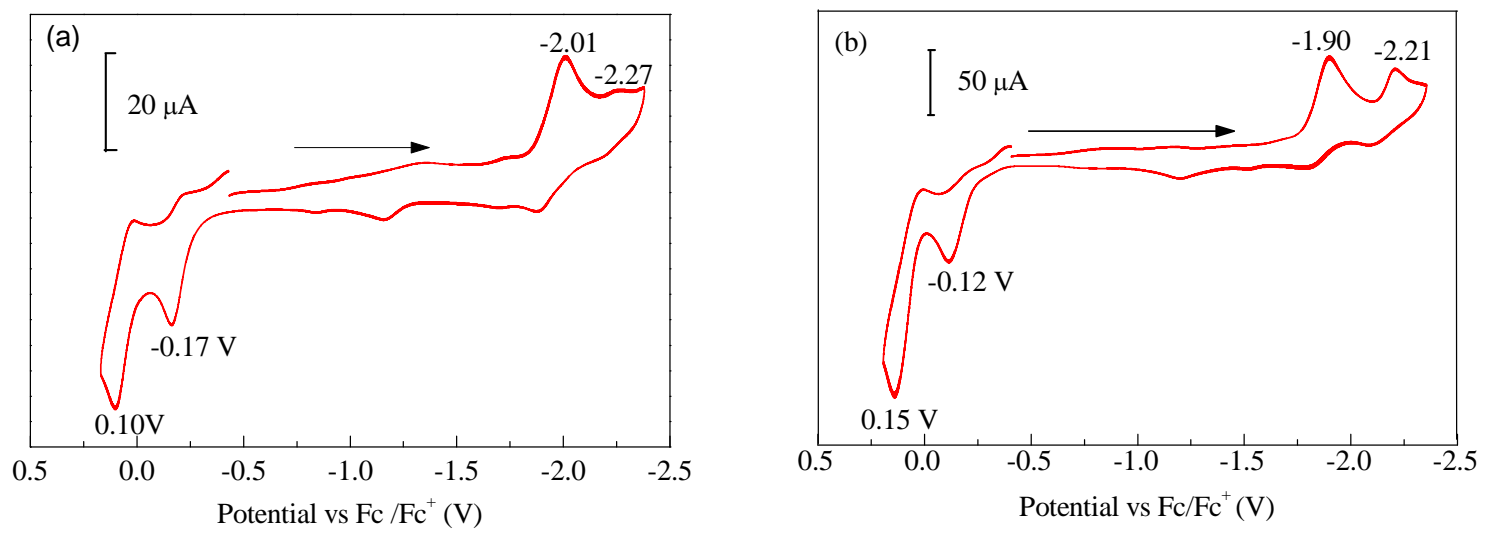

Fig. 5. Cyclic voltammograms of the complexes $(2 \mathrm{~mol} / \mathrm{L})$ in $\mathrm{CH}_{3} \mathrm{CN}$. All potentials are reported vs $\mathrm{Fc} / \mathrm{Fc}^{+}\left(0.1 \mathrm{~mol} / \mathrm{L}\left[n-\mathrm{Bu}_{4} \mathrm{NPF} 6\right]\right.$, scan rate $=100$ $\mathrm{mV} / \mathrm{s}, 22^{\circ} \mathrm{C}$ ). (a) complex 3; (b) complex 4 .

Table 2

Electrochemical data of $\mathbf{3}, \mathbf{4}, \mathrm{A}, \mathrm{B}$, and $\mathrm{C}$ a.

\begin{tabular}{lcccc}
\hline Complex & $E_{\mathrm{pc} 2}\left(\mathrm{Fe}^{\mathrm{II}} / \mathrm{Fe}^{I}\right) / \mathrm{V}$ & $E_{\mathrm{pc} 1}\left(\mathrm{Fe}^{\mathrm{I}} / \mathrm{Fe}^{0}\right) / \mathrm{V}$ & $E_{\mathrm{pa} 1}\left(\mathrm{Fe}^{\mathrm{III}} / \mathrm{Fe}^{\mathrm{III}}\right) / \mathrm{V}$ & $E_{\mathrm{pa} 2}\left(\mathrm{Fe}^{\mathrm{III}} / \mathrm{Fe}^{\mathrm{IV}}\right) / \mathrm{V}$ \\
\hline $\mathbf{3}$ & -2.27 & -2.01 & -0.17 & 0.10 \\
$\mathbf{4}$ & -2.21 & -1.90 & -0.12 & 0.15 \\
$\mathbf{A}$ & -2.34 & -2.15 & 0.10 & - \\
$\mathbf{B}$ & -1.36 & - & 1.26 & - \\
$\mathbf{C}$ & -1.86 & - & 0.60 & - \\
\hline
\end{tabular}

${ }^{\mathrm{a}}$ All potentials versus $\mathrm{Fc} / \mathrm{Fc}^{+}$.

\subsection{Electrochemical study}

Even though the electrochemical properties of many [Fe-Fe]-hydrogenase model complexes have been well discussed[22,23], few Hmd model complexes have been studied electrochemically. We used cyclic voltammetric techniques to determine the electrochemical properties of complex $\mathbf{3}$ and $\mathbf{4}$ and made comparison with the electrochemical behavior of the Hmd model complexes reported previously. The cyclic voltammograms(CV) of $\mathbf{3}$ and $\mathbf{4}$ are shown in Fig. 5. Table 2 lists their electrochemical data along with those of the reported model complexes Fe(3,6-dichloro-1,2-benzenedithiolate)(CO) $\left(\mathrm{PMe}_{3}\right)_{2}$ (A) [24], FeBr(2-acylaminopyridine)(CO)2(PMe3) (B) [25] and [2-C(O) $\left.\mathrm{CH}_{2}-6-\mathrm{PhCO}_{2} \mathrm{CH}_{2} \mathrm{C}_{5} \mathrm{H}_{3} \mathrm{~N}\right]\left[\mathrm{Fe}(\mathrm{CO})_{2} \mathrm{I}\right]$ (C) [26].

Both complexes $\mathbf{3}$ and $\mathbf{4}$ exhibited two irreversible reduction $\left(E_{\mathrm{pc} 1}=-2.01 \mathrm{~V} /-1.90 \mathrm{~V}\right.$ and $\left.E_{\mathrm{pc} 2}=-2.21 \mathrm{~V} /-2.27 \mathrm{~V}\right)$ and two irreversible oxidation $\left(E_{\mathrm{pa} 1}=-0.17 \mathrm{~V} /-0.12 \mathrm{~V}\right.$ and $E_{\mathrm{pa} 2}=1.0$ $\mathrm{V} / 1.5 \mathrm{~V}$ ) versus $\mathrm{Fc} / \mathrm{Fc}^{+}$, respectively. The reduction presumably generated $\mathrm{Fe}^{\mathrm{I}}$ and $\mathrm{Fe}^{0}$ species [24], and the oxidation events were proposed to generate $\mathrm{Fe}^{\mathrm{III}}$ and $\mathrm{Fe}^{\mathrm{IV}}$ species.

The electrochemical behavior of complexes $\mathbf{3}$ and $\mathbf{4}$ is similar to the previously reported complex $\mathbf{A}$ as shown in the Table 2 . For example, two irreversible reduction $\left(E_{\mathrm{pc} 1}\right.$ and $\left.E_{\mathrm{pc} 2}\right)$ of $\mathbf{3}$ and $\mathbf{4}$ were in close proximity with those of complex $\mathbf{A}$ at their respective potentials. The phosphorus ligand combined with the NN ligand played a key role in the large negative shift of its irreversible oxidation $\left(E_{\mathrm{pa} 1}\right)$ and redox potential when compared to those of $\mathbf{B}$ and $\mathbf{C}$ [26]. Complexes $\mathbf{3}$ and $\mathbf{4}$ have one more irreversible oxidation $\left(E_{\mathrm{pa} 2}\right)$ than $\mathbf{A}$ which is an octahedral iron(II) complex with a saturated coordination environ- ment including two strong electron-donating $\mathrm{PMe}_{3}$ ligands. However, the electrochemical behavior of $\mathbf{3}$ and $\mathbf{4}$ was quite different from that of $\mathbf{B}$ and $\mathbf{C}$, which is caused by their quite different coordination spheres.

To investigate the proton reduction property, we conducted the $\mathrm{CV}$ in the presence of $\mathrm{AcOH}$. Complexes $\mathbf{3}$ and $\mathbf{4}$ showed similar redox properties. When $\mathrm{AcOH}$ was added, the current intensity of the original reduction peaks of $\mathbf{3}$ and $\mathbf{4}$ increased continuously with addition of the acid. Comparatively, complex 4 showed a notable increase (Fig. 6). The peak appeared at $-2.21 \mathrm{~V}$ and then shifted gradually to $-2.40 \mathrm{~V}$ with the addition of $\mathrm{AcOH}$. The electric current of $E_{\mathrm{pc} 2}$ linearly increased to 200 $\mu \mathrm{A}$ when the acid $(\mathrm{AcOH})$ quantities were raised $(0,2,3,4,5$,

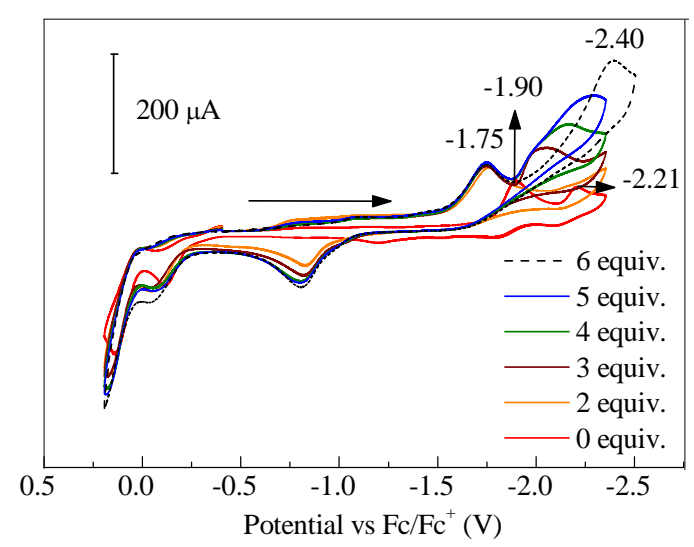

Fig. 6. Cyclic voltammograms of complex 4 (2.1 mmol/L) (red line) with $\mathrm{AcOH}\left(0,2,3,4,5\right.$ and 6 equiv.) (colored lines) in $10 \mathrm{~mL}$ of $\mathrm{CH}_{3} \mathrm{CN}$. All potentials are reported vs $\mathrm{Fc} / \mathrm{Fc}^{+}\left(0.1 \mathrm{~mol} / \mathrm{L} n-\mathrm{Bu}_{4} \mathrm{NPF}_{6}\right.$, scan rate $=$ $100 \mathrm{mV} / \mathrm{s}, 22^{\circ} \mathrm{C}$ ). 
and 6 equiv.), which was suggested to be a feature of catalytic proton reduction. It is notable that the first reduction peak shifted to a positive potential (from $-1.90 \mathrm{~V}$ to $-1.75 \mathrm{~V}$ ) in the presence of $\mathrm{AcOH}$ above 2 equivalent. That was consistent with the protonation of the amine group in other diiron hydrogenase models [22].

\subsection{Protonation and deprotonation}

The active site of Hmd can bind CO to yield a facial tricarbonyl species. However, there was no signal that complexes $\mathbf{3}$ and 4 took up CO under the experimental condition. Furthermore, CO binding reactivity was also not detected by FT-IR when the Lewis acid of $\mathrm{HBF}_{4}$ was added under a $\mathrm{CO}$ atmospheres (1 MPa). Nevertheless, the color of the acetone solution changed from dark purple to orange and the $v(\mathrm{CO})$ spectra was shifted to higher frequency. The carbonyl stretches of protonated complex 3-H+ $\mathbf{H}^{+}$were observed at $2050 \mathrm{~cm}^{-1}$ and 1999 $\mathrm{cm}^{-1}$ and no transient state species or byproduct were observed with the addition of the acid increased up to 6 eqiuv. (Fig. 7). Complex 3 or $\mathbf{4}$ can regenerated with the addition of ethidene diamine. Further experimental results indicated that the reaction was reversible and the protonation/deprotonation
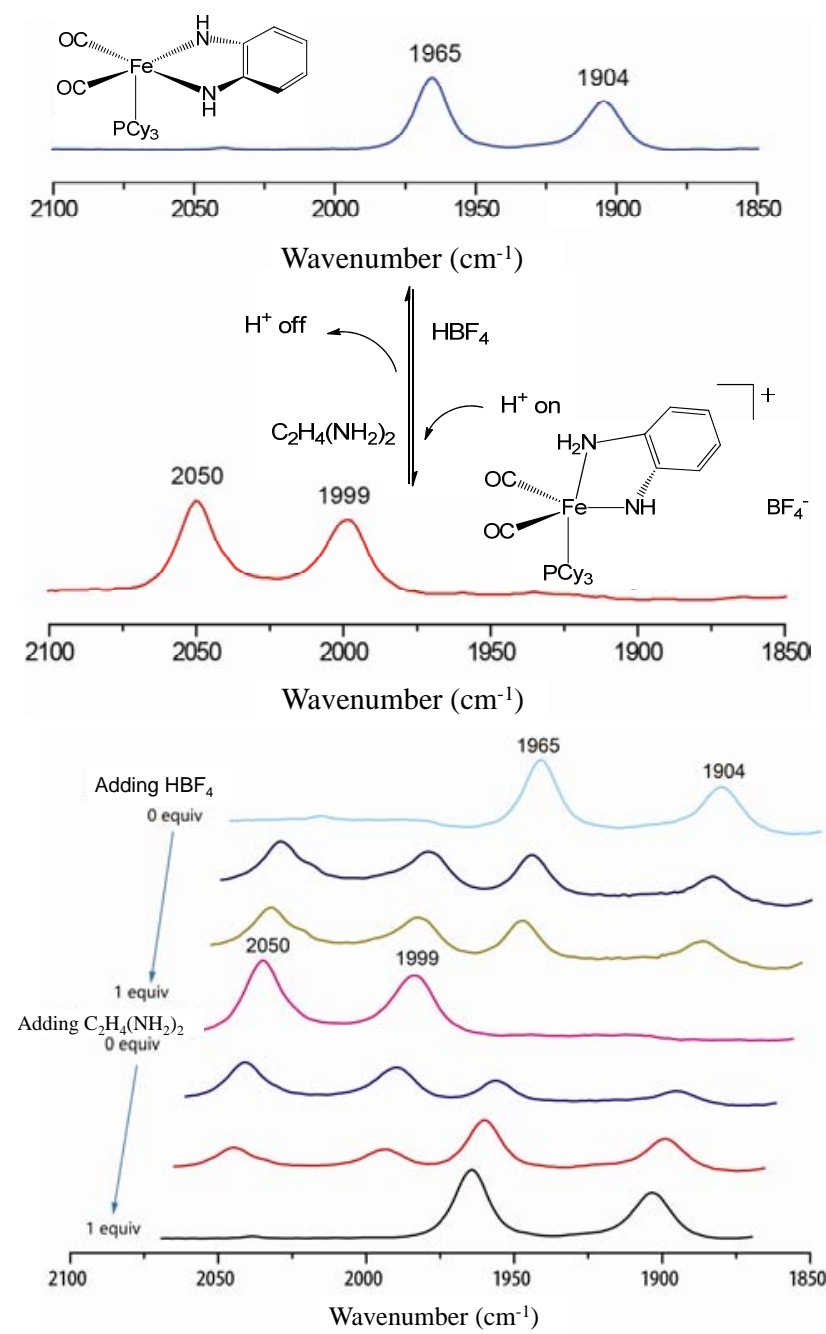

Fig. 7. Protonation and deprotonation of complex 3. process was completed with 1 equiv. $\mathrm{HBF}_{4}$ / ethidene diamine. DFT calculations demonstrated that $\mathrm{H}^{+}$thermodynamically favored combining one of the $\mathrm{N}$ atoms in the protonation. The NN ligand in complex $\mathbf{3}$ or $\mathbf{4}$ would be crucial to the relative stability and observation of the protonated products due to its excellent electron-donor properties. However, the attempt to grow single crystals of $\mathbf{3}-\mathbf{H}^{+}$suitable for X-ray diffraction failed after numerous attempts.

\subsection{Theoretical calculations of the protonation process}

Our previous studies found that the protonated products of $\mathrm{Fe}(\mathrm{CO})_{2} \mathrm{PCy}_{3}(\mathrm{NS})(\mathbf{5}, \mathrm{NS}=2$-aminothiophnol) can only exist by binding another $\mathrm{CO}$ ligand to form the species $\mathbf{5}-\mathbf{C O}-\mathbf{H}^{+}$under a similar protonation condition [19]. The combination of CO is reversible according to the experimental results and DFT calculations. According to the results of the previous experiments, $3-\mathbf{H}^{+}$and $\mathbf{4}-\mathbf{H}^{+}$were stable in acetone solution in the presence of 2-4 equiv. $\mathrm{HBF}_{4}$. It can be inferred from the IR spectrum that protonated products were formed and the protonated species could be $\mathbf{3}-\mathbf{H}^{+}, \mathbf{4}-\mathbf{H}^{+}$or $\mathbf{3}-\mathbf{2} \mathbf{H}^{+}, \mathbf{4}-\mathbf{2} \mathbf{H}^{+}$. Thus, DFT calculations were carried out in order to find the favored structure of protonated 3 and 4. Prior to the calculations of the protonated complexes, we performed DFT calculations for isolated $\mathbf{3}$ and $\mathbf{4}$ with experimental geometry parameters to confirm the validity of the calculation. We found that the optimized geometry parameters were in good agreement with the distance data found experimentally by X-ray diffraction (deviations $<5 \%$ ), indicating the reliability of the calculation method used for the present system.

According to the IR monitor, the protonation was a one-step reaction and no transitional species were formed with the addition of $\mathrm{HBF}_{4}$. Two possible products were taken into consideration and studied by the DFT calculations. As illustrated in Scheme 3, the total free energy of product $3-\mathbf{H}^{+}(-264.97$ $\mathrm{kJ} / \mathrm{mol}$ ) is lower than that of product $\mathbf{3}-\mathbf{2} \mathbf{H}^{+}(-182.17 \mathrm{~kJ} / \mathrm{mol})$. It could be concluded that complex $\mathbf{3}-\mathbf{H}^{+}$is thermodynamically favored. Complex $\mathbf{3}$ is more likely to be protonated on one nitrogen atom of the NN ligand to form the product $3-\mathbf{H}^{+}$. A similar conclusion can be drawn for the protonated product of complex 4.

\subsection{Catalytic hydrogenation of quinone with complex 3}

In the catalytic transfer hydrogenation experiment, the addition of catalyst complex $\mathbf{3}$ facilitated the reduction of quinone substrate. $89 \%$ quinone was converted to hydroquinone with the yield of $40 \%$ in $7 \mathrm{~h}$ at $25{ }^{\circ} \mathrm{C}$ (Fig. 8). The blank control experiment was conducted without the catalyst and showed that hydrogen transfer did not occur. Hence, the catalytic hydrogen transformation was achieved experimental by the mono iron catalyst with $\mathrm{CH}_{3} \mathrm{CH}_{2} \mathrm{OH}$ as the proton source.

\subsection{Proposed mechanism}

According to the experimental results and literature reports [27], a mechanism of transfer hydrogenation involving ethanol 


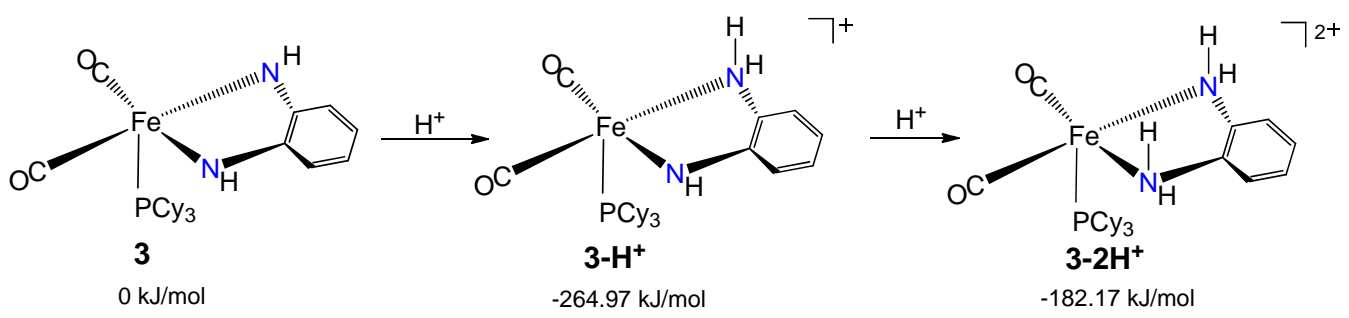

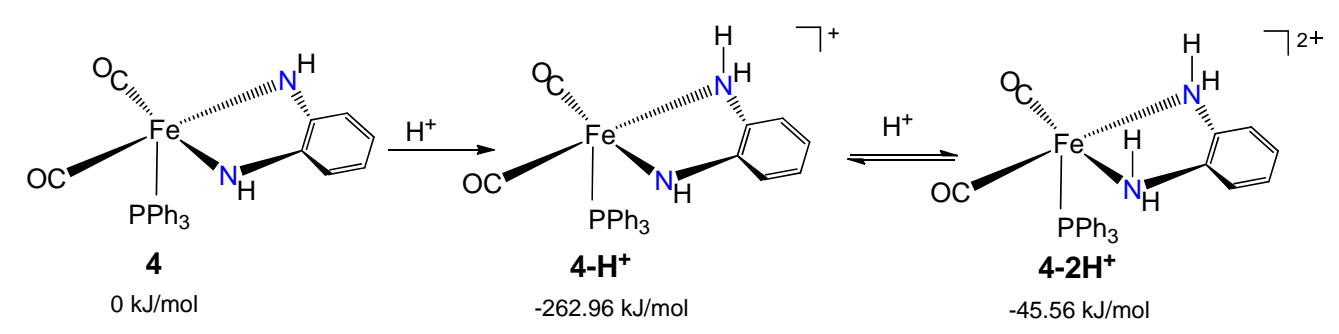

Scheme 3. Total free energy comparison of the proposed protonated products.

heterolytic cleavage was proposed (Scheme 4). The imine-ethanol adduct $\mathbf{6}$ was generated first by hydrogen bonding. Being polarized by the central atom $\mathrm{Fe}$ and imine ligand, ethanol generated the transition state species ts-[3], then the $\mathrm{C}-\mathrm{H}$ and $\mathrm{O}-\mathrm{H}$ bonds were broken successively. With the addition of quinone, a six-membered ring of -Fe-H-C-O-H-N- formed in ts-[4], which stabilized the formed hexatomic ring. The dipole of quinone and easy formation of the O-H-N hydrogen bond contributed to this transformation. Then the hydride transferred from Fe to the carbonyl of quinone and the H-N bond cleaved, finally generating hydroquinone. The adduct ts-[4] was similar to the transition state proved in the DFT calculation of the $[\mathrm{Fe}]$-hydrogenase catalytic process by Hall et al. [12], and it also agreed with Noyori's metal-ligand bifunctional catalytic system [15].
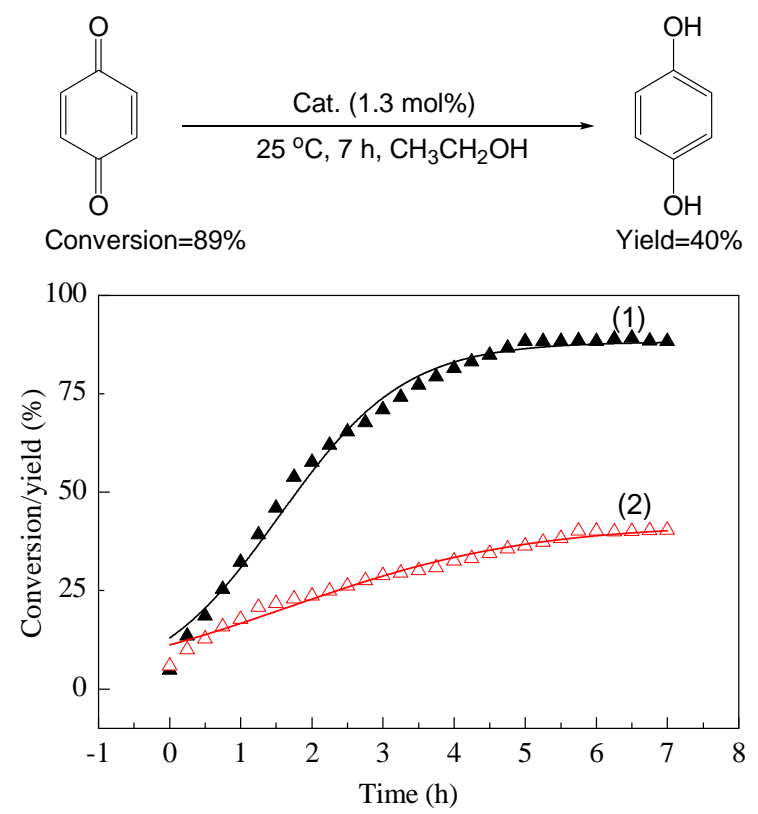

Fig. 8. Dependence of the conversion of quinone (1) and yield of hydroquinone (2) on time at $25{ }^{\circ} \mathrm{C}$ in ethanol solution, $1.3 \mathrm{~mol} \%$ complex $\mathbf{3}$ as catalyst.

\section{Conclusions}

Two pentacoordinate mono iron complexes were synthesized and structurally characterized as models of the [Fe]-hydrogenase active site. The NN ligand in complexes $\mathbf{3}$ and 4 exhibited interesting reversible protonation/deprotonation reactivity. The products formed by nitrogen ligand protonation were detected, which indicated that the NN ligand was a good proton acceptor and probably served as an internal base to accept the proton from $\mathrm{H}_{2}$ before it was delivered to the bulk substrate. This protonation reactivity provides insight into the important role of the internal base in the Hmd function. Complex 3 catalyzed the reduction of benzoquinone in ethanol solution under mild conditions. This study is a progress in the functional mimic of catalytic hydrogenation.

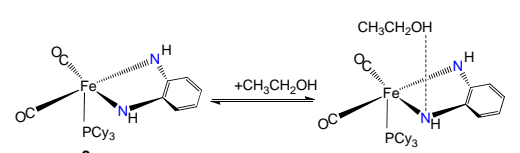<smiles>CCCOC1CCC(O)C1</smiles>

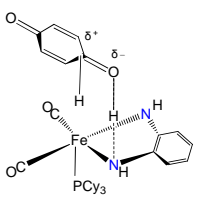

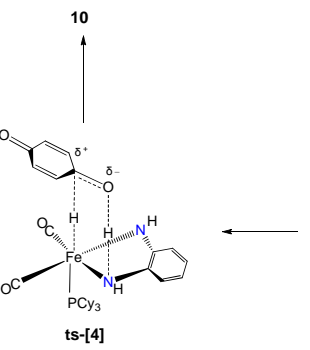$$
\text { ts-[4] }
$$

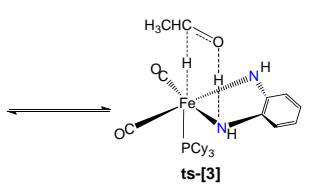
ts-[3]
Scheme 4. Proposed pathway for ethanol activation with quinone. 


\section{Graphical Abstract}

Chin. J. Catal., 2015, 36: 2011-2019 doi: 10.1016/S1872-2067(15)60920-2

Synthesis, characterization and catalytic reactivity of pentacoordinate iron dicarbonyl as a model of the [Fe]-hydrogenase active site

Tianyong Zhang, Liao Sheng, Qiusheng Yang, Shuang Jiang, Yanhong Wang, Chaohui Jin, Bin Li*

Tianjin University; Hebei University of Technology

$\mathrm{Fe}(\mathrm{CO})_{2} \mathrm{PCy}(\mathrm{NN}),\left(\mathrm{NN}=\right.$ phenylenediamine dianion ligand, $\mathrm{N}_{2} \mathrm{H}_{2} \mathrm{Ph}^{2-}$ ) exhibited interesting reversible protonation/deprotonation activity of the diimine ligand similar to the active site of Hmd. The catalytic transfer hydrogenation of benzoquinone to hydroquinone was catalyzed under mild conditions by this model complex with $89 \%$ conversion and $40 \%$ yield.

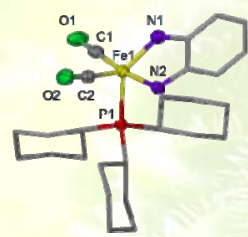

$\mathrm{Fe}(\mathrm{CO})_{2} \mathrm{PCy} \mathrm{y}_{3}(\mathrm{NN})$

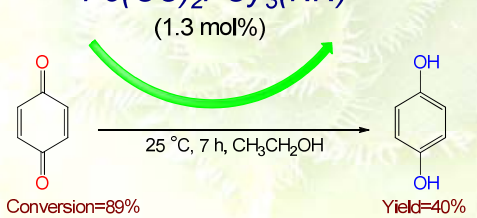

\section{Nomenclature}

$E_{\mathrm{pa}}$-Anodic peak potential, $\mathrm{V}$

$E_{\mathrm{pc}}$-Cathodic peak potential, $\mathrm{V}$

$E_{\mathrm{a}}$-Activation energy, $\mathrm{kJ} / \mathrm{mol}$

\section{References}

[1] Shima S, Thauer R K. Chem Rec, 2007, 7: 37

[2] Thauer R K, Klein A R, Hartmann G C. Chem Rev, 1996, 96: 3031

[3] Fontecilla-Camps J C, Volbeda A, Cavazza C, Nicolet Y. Chem Rev, 2007, 107: 4273

[4] Dey S, Das P K, Dey A. Coordin Chem Rev, 2013, 257: 42

[5] Guo Y S, Wang H X, Xiao Y M, Vogt S, Thauer R K, Shima S, Volkers P I, Rauchfuss T B, Pelmenschikov V, Case D A, Alp E E, Sturhahn W, Yoda Y, Cramer S P. Inorg Chem, 2008, 47: 3969

[6] Hiromoto T, Ataka K, Pilak O, Vogt S, Stagni M S, Meyer-Klaucke W, Warkentin E, Thauer R K, Shima S, Ermler U FEBS Lett, 2009, 583 585

[7] Salomone-Stagni M, Stellato F, Whaley C M, Vogt S, Morante S, Shima S, Rauchfuss T B, Meyer-Klaucke W. Dalton Trans, 2010, 39: 3057

[8] Chen D F, Scopelliti R, Hu X L. J Am Chem Soc, 2010, 132: 928

[9] Shima S, Pilak O, Vogt S, Schick M, Stagni M S, Meyer-Klaucke W, Warkentin E, Thauer R K, Ermler U. Science, 2008, 321: 572

[10] Shima S, Schick M, Kahnt J, Ataka K, Steinbach K, Linne U. Dalton Trans, 2012, 41: 767

[11] Schultz K M, Chen D F, Hu X L. Chem Asian J, 2013, 8: 1068

[12] Yang X Z, Hall M B. J Am Chem Soc, 2009, 131: 10901
[13] Crabtree R H, Siegbahn P E M, Eisenstein O, Rheingold A L, Koetzle T F. Acc Chem Res, 1996, 29: 348

[14] Szymczak N K, Tyler D R. Coordin Chem Rev, 2008, 252: 212

[15] Noyori R, Koizumi M, Ishii D, Ohkuma T. Pure Appl Chem, 2001, 73: 227

[16] Peris E, Lee J C Jr, Rambo J R, Eisenstein O, Crabtree R H. J Am Chem Soc, 1995, 117: 3485

[17] Matsumoto T, Chang H C, Wakizaka M, Ueno S, Kobayashi A, Nakayama A, Taketsugu T, Kato M. J Am Chem Soc, 2013, 135 : 8646

[18] Li B, Liu T B, Popescu C V, Bilko A, Darensbourg M Y. Inorg Chem, 2009, 48: 11283

[19] Liu T B, Li B, Popescu C V, Bilko A, Perez L M, Hall M B, Darensbourg M Y. Chem Eur J, 2010, 16: 3083

[20] Liaw W F, Lee N H, Chen C H, Lee C M, Lee G H, Peng S M. J Am Chem Soc, 2000, 122: 488

[21] Shima S, Lyon E J, Sordel-Klippert M, Kauss M, Kahnt J, Thauer R K, Steinbach K, Xie X L, Verdier L, Griesinger C. Angew Chem. Int. Ed. 2004, 43: 2541

[22] Mejia-Rodriguez R, Chong D, Reibenspies J H, Soriaga M P, Darensbourg M Y.J Am Chem Soc, 2004, 126: 12004

[23] Liu T B, Wang M, Shi Z, Cui H G, Dong W B, Chen J, Akermark B, Sun L C. Chem Eur J, 2004, 10: 4474

[24] Kaur-Ghumaan S, Schwartz L, Lomoth R, Stein M, Ott S. Angew Chem Int Ed, 2010, 49: 8033

[25] Turrell P J, Hill A D, Ibrahim S K, Wright J A, Pickett C J. Dalton Trans, 2013, 42: 8140

[26] Song L C, Hu F Q, Wang M M, Xie Z J, Xu K K, Song H B. Dalton Trans, 2014, 43: 8062

[27] Zuo W W, Lough A J, Li Y F, Morris R H. Science, 2013, 342: 1080

\section{单铁氢化酶五配位模型化合物的合成、表征及催化反应性}

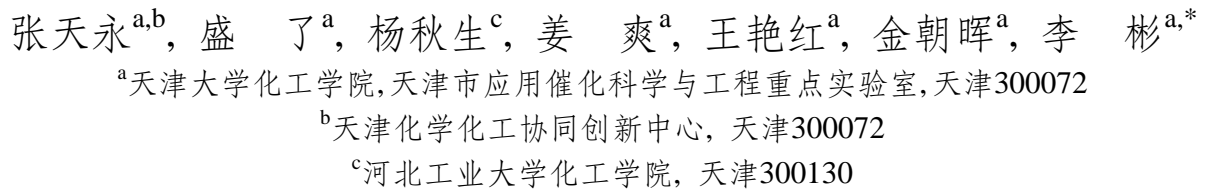


菌在厌氧和镍缺乏的条件下合成的. 区别于其他两种氢化酶, 其活性中心不含Fe-S簇, 且仅含有一个Fe原子, 并且仅能在底物存 在的情况下, 催化异裂氢分子并选择性还原特定底物, 为产甲烷杆菌代谢提供能量. 研究单铁氢化酶的结构和功能, 模拟其活化 氢、利用氢的过程, 对于探索清洁能源的利用和开发新的非贵金属催化剂具有重要意义.

本文以单铁氢化酶(Hmd)结构和功能模拟为导向, 针对单铁氢化酶一级配位结构, 设计合成了两个新模型化合物. 通过IR, NMR, X射线单晶衍射等手段表征分析了模型化合物的性质并确认其结构. 探索了其质子化反应特性、电催化还原质子制氢的特 性. 为了进一步模拟Hmd催化裂解氢气、完成氢转移的功能, 以所合成模型物为催化剂实现了在常温常压下, 以乙醇作为质子源 的催化转移氢化过程.

新单铁模型配合物 $\mathrm{Fe}(\mathrm{CO})_{2} \mathrm{PR}_{3}(\mathrm{NN})(\mathrm{R}=\mathrm{Cy}(3), \mathrm{Ph}(4), \mathrm{NN}$, 邻苯二胺二价阴离子配体) 由 $\mathrm{NN}$ 二齿配体与前体化合物 $\mathrm{Fe}(\mathrm{CO})_{3} \mathrm{I}_{2} \mathrm{PR}_{3}$ 进行配体取代反应合成. 模型化合物活性中心为一个二价铁原子, 拥有两个处于cis-位置的羰基配体, 一个邻苯二胺 双齿配体(两个氮原子进行配位) 以及一个有机膦配体. 通过红外光谱表征所合成的具有不饱和五配位结构化合物的光谱性质, 可 以得到配合物 $\mathrm{Fe}(\mathrm{CO})_{2} \mathrm{PCy}(\mathrm{NN})$ 的羰基红外特征谱峰为 1974, $1919 \mathrm{~cm}^{-1}$, 配合物 $\mathrm{Fe}(\mathrm{CO})_{2} \mathrm{PPh}_{3}(\mathrm{NN})$ 的红外特征谱峰在1985和1929 $\mathrm{cm}^{-1}$ 处. 通过单晶X射线衍射表征确认了两个化合物结构, 并获取晶体学数据.

经研究发现, $\mathrm{Fe}(\mathrm{CO})_{2} \mathrm{PR}_{3}(\mathrm{NN})$ 能够发生酸碱调控下可逆的质子化/脱质子化过程. 基于红外光谱和密度泛函理论计算推断邻 苯二胺阴离子配体可以作为内部碱基. 在酸性条件下, $\mathrm{Fe}(\mathrm{CO})_{2} \mathrm{PR}_{3}(\mathrm{NN})$ 分子内部碱基氮原子通过质子化反应结合一个质子, 生成 $\mathrm{Fe}(\mathrm{CO})_{2} \mathrm{PR}_{3}(\mathrm{NN}) \cdot \mathrm{H}^{+}$. 加入碱之后, 重新生成起始化合物 $\mathrm{Fe}(\mathrm{CO})_{2} \mathrm{PR}_{3}(\mathrm{NN})$. 表明 $\mathrm{N}$ 原子作为内部碱基, 具有结合和转移质子的能力. 该性质与Hmd中半胱氨酸硫配体具有一致性.

通过循环伏安曲线研究了配合物 $\mathrm{Fe}(\mathrm{CO})_{2} \mathrm{PCy}_{3}(\mathrm{NN})$ 和 $\mathrm{Fe}(\mathrm{CO})_{2} \mathrm{PPh}_{3}(\mathrm{NN})$ 的电化学性质. 其中配合物 $\mathrm{Fe}(\mathrm{CO})_{2} \mathrm{PCy}_{3}(\mathrm{NN})$ 和 $\mathrm{Fe}(\mathrm{CO})_{2} \mathrm{PPh}_{3}(\mathrm{NN})$ 均具有两个不可逆的还原峰和氧化峰. 在电化学制氢研究中, 配合物 $\mathrm{Fe}(\mathrm{CO})_{2} \mathrm{PPh}_{3}(\mathrm{NN})$ 的还原峰电流随着乙酸 的加入增幅较大, 展现出较强的催化质子还原的性质. 通过与其他单铁模型配合物对比, 可以推断第一个还原峰归属为配合物由 $\mathrm{Fe}^{\mathrm{II}}$ 转化为 $\mathrm{Fe}$, 第二个可逆还原峰归属为配合物由 $\mathrm{Fe}^{\mathrm{I}}$ 转化为 $\mathrm{Fe}^{0}$. 同时, 配合物 $\mathrm{Fe}(\mathrm{CO})_{2} \mathrm{PPh}_{3}(\mathrm{NN})$ 第一个还原峰向高电位移动, 该现 象与双铁模型化合物的电化学性质较为一致.

进一步研究发现, 模型化合物具有催化转移氢化的活性. 在常温下, 乙醇溶剂中, $\mathrm{Fe}(\mathrm{CO})_{2} \mathrm{PCy}(\mathrm{NN})$ 能够催化对苯醌还原转化 为对苯二酚, 其中对苯醌的转化率达到 $89 \%$, 对苯二酚的产率达到 $40 \%$. 结合实验数据以及文献资料分析, 认为乙醇在催化氢化中 可以作为质子源, 并且提出了催化转移氢化反应过程的机理. 认为催化氢化过程中形成了-Fe-H-C-O-H-N-六元环, 通过分子间相 互作用完成了氢原子转移过程. 该研究结论对单铁氢化酶活性中心模型化合物在催化氢化反应中的应用具有一定的参考价值.

关键词: 单铁氢化酶; 模型化合物; 催化转移氢化; 功能模型物; 对苯醌

收稿日期: 2015-04-16. 接受日期: 2015-05-23. 出版日期: 2015-11-20.

*通讯联系人. 电话/传真: (022)27406610; 电子信箱: libin@tju.edu.cn

基金来源：国家自然科学基金(21103121，21276187); 天津市自然科学基金(13JCQNJC05800); 高等学校博士学科点专项科研基 金(20121317110009).

本文的英文电子版由Elsevier出版社在ScienceDirect上出版(http://www.sciencedirect.com/science/journal/18722067). 